\title{
How editors and publishers perceive their leadership behavior in Chilean and Spanish newsrooms. An approach from transformational leadership
}

\author{
Cómo los editores y directores perciben su estilo de liderazgo en las \\ salas de redacción en Chile y España. Una aproximación desde el \\ liderazgo transformacional.
}

\author{
Benavides, C., Pérez-Latre, F. J., Sánchez-Tabernero, A. \& Bosch, M. J. ${ }^{1}$ \\ Recibido: 11-06-2019 - Aceptado: 12-08-2019 \\ DOI: https://doi.org/10.26441/RC18.2-2019-A3
}

\begin{abstract}
In the media industry, fast innovations and increasing competition require a high degree of corporate leadership (Koryak, Mole, Lockett, et al., 2015). The study of leadership appears to be an increasingly relevant issue. This research aims to find out to what extent leaders (editors and publishers) behave and understand their roles in Chilean and Spanish newsrooms. A questionnaire was applied to measure and identify leadership traits that are considered crucial, thus making possible to acknowledge transformational leaders and differentiate efficient leaders from ineffective. The results show that editors believe they have the ability to inspire, share goals and understand what is important, in contrast with the working experiences of their employees, that often have a low opinion of media companies as places to work.
\end{abstract}

Keywords: leadership; newsroom; media; industry; transformational leadership.

RESUMEN: En la industria de los medios, las innovaciones y la creciente competencia requieren un alto grado de liderazgo para mantenerse vigente (Koryak, Mole, Lockett, et al., 2015). El estudio del liderazgo parece ser un tema cada vez más relevante y esta investigación tiene como objetivo conocer en qué medida los líderes (directores y editores) se comportan y entienden sus roles en las salas de redacción chilenas y españolas. Para eso se aplicó un cuestionario con el objetivo de medir e identificar los rasgos de liderazgo que se consideran cruciales, lo que hace

\footnotetext{
${ }^{1}$ Cristóbal Benavides es Doctor en Comunicación Pública y Máster en Gestión de Empresas de Comunicación por la Universidad de Navarra. Es Vicedecano Académico y Profesor de las asignaturas Taller de Convergencia I, Proyecto Periodístico y Examen de Título de la Facultad de Comunicación de la Universidad de los Andes. cbenavides@uandes.cl, https://orcid.org/0000-0001-5573-6785
}

Francisco Javier Pérez-Latre es Doctor en Comunicación Pública por la Universidad de Navarra y Master of Arts en Marketing Communications/Advertising por Emerson College, Boston. Es Director Académico del Máster en Gestión de Empresas de Comunicación y Profesor Titular de Periodismo de la Facultad de Comunicación de la Universidad de Navarra. perezlatre@unav.es, https://orcid.org/0000-0002-9844$\underline{3496}$

Alfonso Sánchez-Tabernero es Doctor en Ciencias de la Información y actual Rector de la Universidad de Navarra. Es Profesor de Empresa Informativa de la Facultad de Comunicación y PDG por el IESE de la misma universidad, así como Visiting Fellow del European Institute for the Media (Dusserldorf). astabernero@unav.es, https://orcid.org/0000-0003-3392-1861

María José Bosch es Doctora en General Management y Master of Research in Management del IESE Business School de la Universidad de Navarra. Es Profesora Asociada de Dirección de Personas y Directora del Centro de Investigación Conciliación Trabajo y Familia del ESE Business School de la de la Universidad de los Andes. mjbosch.ese@uandes.cl, https://orcid.org/0000-0001-9745-433X 
posible reconocer a los líderes transformacionales y diferenciar a los líderes eficientes de los ineficaces. Los resultados muestran que los editores creen que tienen la capacidad de inspirar, compartir objetivos y comprender lo que es importante, en contraste con las experiencias laborales de sus empleados, que a menudo tienen una opinión no del todo favorable.

Palabras clave: liderazgo; salas de redacción; industria de medios; liderazgo transformacional

\section{Introduction ${ }^{2}$}

Digital technologies have changed the "game rules" in almost every product and service market. Nowadays, media firms should be extremely flexible and creative to protect their market shares against old and new rivals (Pérez-Latre, 2014). Quick innovations and more competition in the media industry demand a high degree of corporate leadership (Dal Zotto \& Van Kranenburg, 2008; Koryak, Mole, Lockett, et al., 2015). Without changes, companies are left behind. Often transformations are not quiet and linear, as they require new strategies, business models and processes to create and generate value (Nieves et al., 2014). In summary, leadership has become one of the main sources of competitive advantages (Jaiswal and Dhar, 2015).

Our research aims to test how leaders (editors and publishers) behave and understand their role in Chilean and Spanish news media. We would like to identify whether they aspire to foster the necessary industry innovations with a long-term vision as it has been proved that decisions oriented just to get immediate results without considering quality have a potential to generate more damage than profits.

\section{Reference framework}

\subsection{Transformational leadership: change for the organization's good}

The study of leadership in the media industry appears to be an increasingly promising research venue. The ever-changing nature of the industry combined with disappearing entry barriers and a tendency to "democratization" is leading to the perception that people become the key "asset" for editorial and commercial success.

Many authors have listed the qualities leaders must have (Fairhurst \& Connaughton, 2014; Peters, 1987; Bennis, 1989; Kotter, 1982; Yukl, 2002). They can be grouped in four characteristics: (1) A clear idea of what they want to achieve; (2) passion and capacity to inspire; (3) integrity, sincerity and trustworthiness, but also (4) curiosity and daring. According to Bass (1999), leaders are a different breed: they can foster working environments that are attractive and innovative to employees' eyes. They have the ability to plan improvements and integrate efforts and motivation so that results make a difference both internally and externally.

In the last decade, an abundant number of leadership concepts have been proposed: it is difficult to establish specific definitions (Northouse, 2004). However, many of them have something in common: leadership is considered as an influence process where every leader has one or more followers (Vroom \& Jago, 2007). More recently, researchers have looked into the identification and classification of different leadership styles, approaches

\footnotetext{
${ }^{2}$ This work was supported by Conicyt, under Grant Fondecyt № 11150020.
} 
or types. Some authors (Rubin et al., 2005; Jackson et al., 2013) consider that it is useful to distinguish between corrective, transactional and transformational leadership.

Corrective Leadership is established when leaders try to redress mistakes and deviations: the kind of actions that have to be carried out when something goes wrong (Bass, 1999). This model is related to "laissez-faire" or even the absence of leadership that appears when leaders avoid taking decisions or when they are not present to clarify doubts and solve problems.

Transactional Leadership is rooted on individualized considerations: leaders give their subordinates a differentiated treatment, according to their needs and capacities; they also provide contingent rewards that refer to the process in which constructive transactions between leaders and followers are established (Judge \& Piccolo, 2004). At this point, expectations are clearer and the rewards that will be granted with the fulfillment of goals are specifically established.

Transformational leadership is based on processes that facilitate change in the persons that are part of an organization. Leaders allow their employees to elevate themselves beyond individual goals to embrace collective ones. Burns (2003) relates transformational leadership to leaders that appeal the intrinsic motivations to generate changes in working teams. Bass (1999) describes it from the effect it produces on followers: motivation and self-esteem are the key tools for change that lead companies to improve their performance. The value of results is good not just for them but for the organization as a whole: personal motivations become global motivations (Men, 2014). Such leaders work on emotions, values, ethics, standards and the satisfaction of needs to fulfill their goals.

Podsakoff et al. (1990) go a bit further, underlying six key behaviors of transformational leaders: a) give an intellectual stimulus that challenges subordinates; b) articulate a vision for the future of the organization that inspires; c) build models of supervision that offer guidance to collaborators; d) foster the acceptance of group goals in order to reach a common goal; e) provide individual support to understand the personal and specific motivation on each team member; f) establish demanding but achievable performance goals communicating the expectation that future results will improve the present ones.

The common denominator is the change that leaders provoke in their followers. In order to achieve that goal, it is necessary to work generating strong ties of engagement and appeal to long term motivations (Tansky \& Cohen, 2001). As a result, a number of positive attitudes are generated that facilitate problem-solving and help to face new challenges: there is more openness to feedback, and criteria for individual decisions are fine-tuned (Gillet \& Vandenberghe, 2014).

From a conceptual standpoint, transformational leaders show a wide array of behaviors (Bass \& Riggio, 2006): they are examples to follow (charisma), give meaning to their subordinate's actions (inspiration), encourage the search for alternative solutions to routine problems (intellectual stimulus), and are generally concerned for the individual needs of employees (personalized attention). Besides, as transformational leadership tends to be also inspirational, it tends to connect deeply with people leading to growth and personal development (Chalofsky \& Krishna, 2009). Bass \& Avolio (1994: 48) say that transformational leadership happens when leaders reward or punish their followers according to the work's quality. Therefore, it depends on the effort levels. 


\subsection{Leadership, creativity and innovation}

Transformational leaders are able to create a culture of change in their organizations: they do not tolerate employees that are just looking at their comfort zone, they help them to avoid the fear to risk and to work in a creative way. Such environment is the first step to foster an innovative spirit (Amabile, 1998). Creativity is considered a long term bet, as opposed to a quick way to find solutions to present and specific problems (Imran, Ilyas, Aslam \& Fatima, 2018).

The more effective competitive advantages are related to creative processes, ideation, talent and knowledge. To achieve those goals it becomes necessary to establish formal processes that can allow the replication of such processes so that they do not become isolated events but practices that become established: in this way experiences become good practice and learning for the organizations.

Transformational leaders have learned that in order to reach creative solutions the different company areas must be aligned so that creative abilities are improved throughout the organization. Such strategic orientation is a source of opportunities that could lead to an environment where breakthrough innovations become frequent.

Creativity is built in organizations by fostering the interaction of four components with decisive influence in our attitudes to work: creative thinking, environment, experience and motivation (Amabile, 1998). The environment in which a person develops is the first factor. In more competitive environments, the possibilities to increase creativity grow. The second factor that influences creativity is each person's experience: all the things that a person has learned can be transformed into new solutions for the organization. Another element comes from creative thinking: the ability to group already existing ideas in brand new combinations. Such skill depends both on personality, the person's way of thinking and working, and also his or her degree of market knowledge.

When individuals feel they are supported by leaders that foster a company-wide flow of knowledge, there is an increase in their contribution to their companies' development (Wang, 2010). After researching employees' relationships with their superiors, Zhang \& Bartol (2010) conclude that the higher the involvement of employees, leaders and organizations in creative processes, the higher the chances to improve ROI for a company.

Innovation has become the key element to achieve long term results, regardless industry and sector (Hon, 2012). Leadership generates employees' commitment, and such commitment fosters innovation. Cerne et al. (2013), for example, studied the correlation between 300 employees and their leaders and found out that leadership has a direct influence on the degree of "corporate innovation": people are able to sort out problems and can face new challenges if they feel they have internal support and recognition (Afuah, 2014).

\subsection{Leadership in the media industry}

The media industry landscape has experienced deep adjustments since 2008: "Across our 26 countries (analyzed), we see a common picture of job losses, cost-cutting, and missed targets as falling print revenues combined with the brutal economics of digital in a perfect storm” (Reuters Institute, 2016).

The growth of competitors outside the traditional media industry's boundaries also had an impact on the business. Audience's migration to new platforms has led to a steep 
decline in advertising, single-copy sales and subscribers in print media. The old incumbent media organizations, like Time-Warner, Bertelsmann or News Corp, should compete now with telecommunication and online firms: Google, Apple and Facebook are dominant in the content distribution and advertising markets. According to Mitchell and Holcomb (2016) these companies already own $70 \%$ of the online advertising space.

To face such difficult task, transformational leaders may use the lever of intrinsic motivation (Cardona, 2000): every person working in a media firm is well aware of the effects of content delivered by media organizations in society. Kiarie, Maru, and Cheruiyot (2017) showed that extroverted leaders, with emotional stability and willing to create new experiences, generate positive effects on employee job satisfaction.

Almost any employee looks forward to participate in projects that develop his or her intellectual abilities: such goal can easily be achieved in creative organizations like news media firms. In addition, such companies can provide opportunities for internal mobility. This vision of the world of work demands strong efforts to acquire, keep and motivate people. This is a difficult goal as media executives often bemoan the lack of motivation in their employees and the shortage of qualified staff for some essential departments in their organizations (Colbert, Barrick \& Bradley, 2014).

Breevaart and Bakker (2018) argue that the behavior of transformational leaders allows the generation of employee commitment and thus may reduce turnover even in short-term and temporary missions. Chile and Spain are not exceptions to this general rule. Mellado, Salinas, Valle \& González (2010) confirmed it in their study of four regional capitals of Chile that analyzes the job market and journalist's professional profiles. They found that seven out of ten journalists have had between two and fifteen different jobs in the last three years, being those under forty years old the ones with higher mobility and turnover.

The picture in Spain does not look any better. Palacio Llanos (2015) published a report based on a survey conducted with 20.000 journalists affiliated to the Association of Spanish Journalists. Only 43,5 percent of the 2.423 people who answered the questionnaire considered their working conditions as fair; 58,3 percent declared that they were satisfied with their job; and 65 percent said that in the future they will probably work as independent news providers, not as employees of media firms.

The new competitive landscape demands an increased emphasis in the development of leadership abilities inside media firms. Transformational leadership has a significant influence in working satisfaction and commitment in organizations (Atmojo, 2015). Working satisfaction has a positive and significant influence on employee performance. Such virtuous cycle (motivation, commitment, work satisfaction) makes possible to foster organization's innovative spirit (Shanker, Bhanugopan, Van der Heijden \& Farrell, (2017).

Uusi-Kakkuri (2017), consider that transformational leadership is an appropriate style for the leadership of creative people, this is particularly beneficial for this industry that is based on its success in generating creative and quality content day by day. Also she considers that the most transformational leaders are creative as well, which indicates that they are in good position to lead innovators, and as we have seen this will be key to stay in front of the great existing competition.

In general, studies about leadership in the media industry have not been abundant. PérezLatre \& Sánchez-Tabernero (2003) were among the first to explore the field showing that in media companies radical transformations do not come about without the existence of one or several leaders, capable of mobilising the organisation where they work. Küng 
(2006), Benavides $(2012 ; 2017)$ and Deslandes (2016) are among the few authors that have looked into the role of leadership in the media industry.

\section{Methodology and research questions}

The general objective of the study is to find out if the directors and editors of Chilean and Spanish news media perceive themselves as transformational leaders, and how this leadership style benefits to their organizations. We consider that Chilean and Spanish market are faced with similar problems: a lot and new competitors; fragmented audience (Álvarez, 2016; Sánchez y de la Cavada, 2018); and constant decline in advertising investment (Achap, 2018; InfoAdex, 2018).

This is the context in which our three research questions are established:

Q1 How do news media managers perceive their own leadership styles?

We hypothesize that many news firms are not taking advantage of their potential to foster creativity and innovation because of their lack of efficient leadership at the top of the organizations. That explains that the most radical and successful changes in the industry come from new players, many of them coming from other non-related product markets. In many cases, such lack of leadership is not adequately identified by the managers and becomes "endemic". Following our point, we guess that publishers and editors overestimate their leadership skills. Therefore, our goal with this question is to measure the perceptions of Chilean and Spanish managers about their ability to lead news media companies.

Q2 Is there a match between leadership theory (generation of innovative environments in creative industries) and editors and managers perceptions of their management tasks?

In media environments, intangible assets are crucial: talented and motivated teams should produce innovative contents which can conquer the attention and trust of the audience. There is a solid body of research that points out to the kind of leadership needed in those creative contexts. Managers should not give orders but inspire people (Zhang \& Bartol, 2010). And micromanagement should be replaced by participatoy decission-making processes (Men, 2014). With this second question, we would like to compare theory and the industry leaders' perceptions. In other words, we would like to verify if leaders use the frames and tools that are considered essential to generate value in "knowledge creating companies" and promote the innovation according to the literature.

Q3 Is there any correlation between leadership practices and i) firms' size, ii) distribution systems or platforms used, iii) years of existence, and iv) type of ownership?

Media firms deliver news and entertainment content to their audiences. But they differ in many ways: they have different size and scope; they distribute their offers through print media, radio or television broadcasting, cable and satellite and the internet; they are owned by the state, by individuals or families or they have a diversified ownership if they are quoted in the stock exchange. We would like to discover whether each one of those options has an impact on the kind of leadership practiced in news organizations.

To find the right answers to our three questions, we have sent a questionnaire to managers and editors of Chilean and Spanish news media. The research instrument is made of three parts. The first is the Multifactor Leadership Questionnaire 5X, commonly known as MLQ5x. It was developed by Bass \& Avolio (2000). This instrument is validated for (Mittal \& Dhar, 2015; Qu, Janssen, \& Shi, 2015; Pilbeam, Doherty, Davidson, \& Denyer, 
2016; Zwingmann, Wegge, Wolf, Rudolf, Schmidt, \& Richter, 2014; Aga, Noorderhaven, \& Vallejo, 2016; Jensen, Andersen, Bro, Bøllingtoft, Eriksen, Holten \& Westergård-Nielsen, 2019) and is considered the best method to measure this kind of issues and the most research style study in academic journals (Eberly, Bluhm, Guarana, Avolio, \& Hannah, 2017; Antonakis, \& Day, 2017).

It uses 45 statements that measure and identify nine key leadership traits. It makes possible to acknowledge transformational leaders and differentiate efficient leaders from ineffective leaders. All items were answered using a 5-point Likert scale where $0=$ totally disagree and $4=$ totally agree.

The nine sub variables are grouped in three higher order variables (Figure 1): Transformational Leadership, Transactional Leadership and Corrective Leadership. The first higher order variable corresponds to Transformational Leadership that is made up of charisma or idealized influence: it measures the degree in which leaders behave in such a way that followers identify with him or her. That dimension is composed by a) Idealized attributed influence that allows knowing whether leaders are perceived as powerful and trustworthy, focused on ideals and higher order ethics; b) Idealized conductual influence that refers to charismatic actions by a leader that are centered in beliefs and values; c) Inspirational motivation is a mechanism that allows leaders to articulate their vision and motivate their collaborators with long term goals. Table 1 shows also the variables corresponding to transactional and corrective leadership.

Table 1. MLQ variables

\begin{tabular}{|l|l|l|l|}
\hline Variables & Indicators & $\begin{array}{l}\text { Acrony } \\
\mathbf{m}\end{array}$ & $\begin{array}{l}\text { Number of } \\
\text { items in the } \\
\text { questionnaire }\end{array}$ \\
\hline $\begin{array}{l}\text { Transformational } \\
\text { leadership }\end{array}$ & $\begin{array}{l}\text { 1. Idealized attributed } \\
\text { influence } \\
\text { 2. Idealized behavioral } \\
\text { influence } \\
\text { 3. Inspirational motivation } \\
\text { 4. Intellectual stimulation } \\
\text { 5. Individualized } \\
\text { consideration }\end{array}$ & $\begin{array}{l}\text { IAI } \\
\text { IBI } \\
\text { IM }\end{array}$ & 20 \\
IS & IC & \\
\hline $\begin{array}{l}\text { Transactional } \text { Contingent rewards } \\
\text { leadership }\end{array}$ & $\begin{array}{l}\text { 2. Management-by-exception } \\
\text { active }\end{array}$ & MBE-A & 8 \\
\hline $\begin{array}{l}\text { 1. Management-by-exception } \\
\text { passive } \\
\text { 2. Laissez-faire }\end{array}$ & MBE-P & 8 \\
\hline leadership & \multicolumn{1}{|c|}{ Source: Own elaboration. } & LF & \\
\hline
\end{tabular}

The second part of the questionnaire is built to understand the relationships between leadership, creativity and innovation. In order to achieve that goal a tool developed by Zhou and George (2001) was used. It includes a series of variables that were summarized in five items: motivation, innovation, audience, participation and talent. The final part 
tries to find out whether the size, distribution system (print, audiovisual or online) and type of ownership have any relationship with the kind of leadership of each news organization.

The survey was sent twice by email to a database of more than 400 professionals that were. After that, in order to improve response rates, some participants were also visited in their workplaces. The response rate reached (around 25\%) allowed us to get 50 valid questionnaires from each country. The sample $-85 \%$ men, $15 \%$ women- includes managers from radio, television, newspapers, magazines and the web of the most relevant media companies from each country. The average age of the participants was 45 years. With 78 people on average in their teams, which shows a relevant number of people in charge. Regarding the years in management positions, they have been on average 10 years. All of them are journalists by profession.

\section{Results: Leaders' self-perceptions}

According to the results obtained (table $2 \& 3$ ), the directors and editors in Chile and in Spain consider themselves as transformational leaders, with inspirational motivation (mean: 3.29; mean: 3.17) being the indicator with the highest average. This means that they see as herself as people who believe they inspire others, articulate shared goals and understand what is right and important, thus providing insights to achieve common objectives (Avolio \& Bass, 2004). All those qualities seem to be desirable in the media industry where there is evidence that suggests that more motivated workers will increase their productivity along with their work satisfaction (Czech \& Forward, 2013).

Table 2. Mean and standard deviation (SD) Total, Chile and Spain

\begin{tabular}{|c|c|c|c|c|c|c|c|c|c|}
\hline \multirow[b]{2}{*}{ Variable } & \multicolumn{3}{|c|}{ Total } & \multicolumn{3}{|c|}{ Chile } & \multicolumn{3}{|c|}{ Spain } \\
\hline & Mean & SD & Range & Mean & SD & Range & Mean & SD & Range \\
\hline $\begin{array}{l}\text { Idealized attributed } \\
\text { influence }\end{array}$ & 3.03 & 0.58 & $0-4$ & 3.03 & 0.63 & $0-4$ & 3.02 & 0.54 & $0-4$ \\
\hline $\begin{array}{l}\text { Idealized behavioral } \\
\text { influence }\end{array}$ & 3.14 & 0.64 & $0-4$ & 3.15 & 0.61 & $0-4$ & 3.13 & 0.67 & $0-4$ \\
\hline $\begin{array}{l}\text { Inspirational } \\
\text { motivation }\end{array}$ & 3.16 & 0.55 & $0-4$ & 3.28 & 0.57 & $0-4$ & 3.04 & 0.50 & $0-4$ \\
\hline $\begin{array}{l}\text { Intellectual } \\
\text { stimulation }\end{array}$ & 3.14 & 0.48 & $0-4$ & 3.24 & 0.43 & $0-4$ & 3.04 & 0.50 & $0-4$ \\
\hline $\begin{array}{l}\text { Individual } \\
\text { consideration }\end{array}$ & 3.13 & 0.55 & $0-4$ & 3.18 & 0.56 & $0-4$ & 3.09 & 0.55 & $0-4$ \\
\hline Contingent reward & 3.16 & 0.50 & $0-4$ & 3.24 & 0.49 & $0-4$ & 3.07 & 0.49 & $0-4$ \\
\hline $\begin{array}{l}\text { Management-by- } \\
\text { exception active }\end{array}$ & 2.39 & 0.69 & $0-4$ & 2.51 & 0.69 & $0-4$ & 2.27 & 0.67 & $0-4$ \\
\hline $\begin{array}{l}\text { Management-by- } \\
\text { exception passive }\end{array}$ & 0.83 & 0.70 & $0-4$ & 0.65 & 0.54 & $0-4$ & 1.01 & 0.80 & $0-4$ \\
\hline Laissez-faire & 0.48 & 0.65 & $0-4$ & 0.44 & 0.50 & $0-4$ & 0.51 & 0.78 & $0-4$ \\
\hline
\end{tabular}

The values correspond to the mean obtained from a Likert scale of five points per element $(0=$ never, 1=occasionally, 2=sometimes, $3=$ often, 4=always) n: 52 for all answers.

Source: Own elaboration. 
Idealized behavioral influence shows high scores (Chile mean: 3.26; Spain's mean: 3.24) that are usual for leaders with behaviors that are considered excellent like mastery, awareness, optimism or self-control (Avolio \& Bass, 2004). Such scores underline their most relevant beliefs, including ethical and moral values. Xiaoming, George \& Cong (2013) showed that integrity is a crucial value for journalists as they consider it part of their public mission and societal role. Leaders with high idealized influence scores are also considered to be dedicated to building a shared vision and mission for their teams.

Comparing our two groups, we run an ANOVA test to check for the difference between the Chilean and the Spanish sample:

Table 3. ANOVA test between the Chilean and the Spanish sample

\begin{tabular}{|l|c|c|c|}
\hline Variable & MS & F & Prob \\
\hline Idealized attributed influence & 0.01 & 0.02 & 0.88 \\
\hline Idealized behavioral influence & 0.02 & 0.04 & 0.84 \\
\hline Inspirational motivation & 1.44 & 5.02 & 0.03 \\
\hline Intellectual stimulation & 1.07 & 4.80 & 0.03 \\
\hline Individual consideration & 0.20 & 0.66 & 0.42 \\
\hline Contingent reward & 0.74 & 3.02 & 0.09 \\
\hline Management-by-exception active & 1.42 & 3.07 & 0.08 \\
\hline Management-by-exception passive & 2.95 & 6.31 & 0.01 \\
\hline Laissez-faire & 0.12 & 0.28 & 0.60 \\
\hline
\end{tabular}

Source: Own elaboration.

Results show that there is a significant difference between Chile and Spain in Inspirational motivation $(\mathrm{p}<0.05)$, Intellectual stimulation $(\mathrm{p}<0.05)$, and Managementby-exception passive $(\mathrm{p}<0.01)$. Such results suggest the importance given to innovative thinking that can support employees' ideas and values, especially those that question processes or work practices they consider obsolete or inappropriate to face new challenges (Avolio \& Bass, 2004). In such way, creativity and efficiency are both fostered and there is a sort of intellectual contagion in working teams. Intellectual stimulation appears to be apt for the news media industry that needs to challenge old ways embracing the new consumption patterns that are increasingly adopted by audiences (Jenkins, Ford, \& Green, 2013).

Editors do not see lack of leadership in themselves: "management-by-exception passive and laissez-faire" were the least self-perceived characteristics. It corresponds to leadership styles that have difficulties assuming duties and responsibilities (Skogstad, Einarsen, Torsheim, Aasland, \& Hetland, 2007). Its mean was 0.65 and 0.44 respectively in Chile, versus 1.01 and 0.51 in Spain. The landscape was quite similar in both countries, where directors and publishers see themselves as involved, solution-oriented and decisive leaders that solve problems along the way. 
Table 4. Comparison of variables by type of media, Chile

\begin{tabular}{|c|c|c|c|c|c|c|c|c|c|c|}
\hline \multirow[b]{2}{*}{ Variable } & \multicolumn{2}{|c|}{ Total } & \multicolumn{2}{|c|}{ Press } & \multicolumn{2}{|c|}{ Radio } & \multicolumn{2}{|c|}{ TV } & \multicolumn{2}{|c|}{ Web } \\
\hline & Mean & SD & Mean & SD & Mean & SD & Mean & SD & Mean & SD \\
\hline $\begin{array}{l}\text { Idealized attributed } \\
\text { influence }\end{array}$ & 3.03 & 0.63 & 2.91 & 0.69 & 3.08 & 0.39 & 3.24 & 0.60 & 3.10 & 0.42 \\
\hline $\begin{array}{l}\text { Idealized behavioral } \\
\text { influence }\end{array}$ & 3.15 & 0.61 & 3.00 & 0.68 & 3.22 & 0.54 & 3.40 & 0.47 & 3.22 & 0.19 \\
\hline Inspirational motivation & 3.28 & 0.57 & 3.21 & 0.52 & 3.46 & 0.33 & 3.41 & 0.68 & 2.92 & 0.80 \\
\hline Intellectual stimulation & 3.24 & 0.43 & 3.17 & 0.48 & 3.35 & 0.22 & 3.44 & 0.39 & 3.00 & 0.25 \\
\hline Individual consideration & 3.18 & 0.56 & 3.07 & 0.58 & 3.33 & 0.44 & 3.38 & 0.57 & 2.83 & 0.14 \\
\hline Contingent reward & 3.24 & 0.49 & 3.17 & 0.52 & 3.25 & 0.45 & 3.48 & 0.45 & 2.92 & 0.14 \\
\hline $\begin{array}{l}\text { Management-by- } \\
\text { exception active }\end{array}$ & 2.51 & 0.69 & 2.53 & 0.61 & 2.38 & 0.67 & 2.64 & 0.90 & 2.00 & 0.25 \\
\hline $\begin{array}{l}\text { Management-by- } \\
\text { exception passive }\end{array}$ & 0.65 & 0.54 & 0.69 & 0.57 & 0.80 & 0.48 & 0.50 & 0.47 & 0.88 & 0.88 \\
\hline Laissez-faire & 0.44 & 0.50 & 0.47 & 0.53 & 0.25 & 0.39 & 0.38 & 0.44 & 0.83 & 0.80 \\
\hline
\end{tabular}

Source: Own elaboration.

Table 5. Comparison of variables by type of media, Spain

\begin{tabular}{|l|c|c|c|c|c|c|c|c|c|c|}
\hline & \multicolumn{2}{|c|}{ Total } & \multicolumn{2}{c}{ Press } & \multicolumn{2}{c|}{ Radio } & \multicolumn{3}{c|}{ TV } & \multicolumn{3}{c|}{ Web } \\
\hline Variable & Mean & SD & Mean & SD & Mean & SD & Mean & SD & Mean & SD \\
\hline $\begin{array}{l}\text { Idealized attributed } \\
\text { influence }\end{array}$ & 3.02 & 0.54 & 2.84 & 1.40 & 3.16 & 0.33 & 3.04 & 0.25 & 3.19 & 2.80 \\
\hline $\begin{array}{l}\text { Idealized behavioral } \\
\text { influence }\end{array}$ & 3.13 & 0.67 & 3.00 & 0.65 & 3.87 & 0.18 & 3.03 & 0.82 & 3.28 & 0.33 \\
\hline Inspirational motivation & 3.04 & 0.50 & 3.04 & 0.55 & 3.40 & 0.14 & 2.84 & 0.45 & 3.13 & 0.44 \\
\hline Intellectual stimulation & 3.04 & 0.50 & 3.10 & 0.48 & 3.05 & 0.48 & 2.91 & 0.66 & 2.96 & 0.29 \\
\hline Individual consideration & 3.09 & 0.55 & 3.08 & 0.61 & 3.25 & 0.47 & 2.91 & 0.44 & 3.29 & 0.51 \\
\hline Contingent reward & 3.07 & 0.49 & 3.13 & 0.50 & 2.80 & 0.62 & 2.95 & 0.49 & 3.25 & 0.35 \\
\hline $\begin{array}{l}\text { Management-by- } \\
\text { exception active }\end{array}$ & 2.27 & 0.67 & 2.29 & 0.67 & 2.56 & 0.72 & 1.98 & 0.74 & 2.54 & 0.37 \\
\hline $\begin{array}{l}\text { Management-by- } \\
\text { exception passive }\end{array}$ & 1.01 & 0.80 & 1.12 & 0.92 & 0.80 & 0.91 & 0.91 & 0.56 & 0.83 & 0.54 \\
\hline Laissez-faire & 0.51 & 0.78 & 0.63 & 0.92 & 0.30 & 0.41 & 0.52 & 0.64 & 0.05 & 0.11 \\
\hline
\end{tabular}

Source: Own elaboration.

To check if there is any difference between the type of media, we run an ANOVA test. Results are presented in table 6 . 
Table 6. ANOVA test between different type of media

\begin{tabular}{|l|r|r|r|}
\hline Variable & \multicolumn{1}{|c|}{ MS } & \multicolumn{1}{|l|}{ F } & \multicolumn{1}{|c|}{ Prob } \\
\hline Idealized attributed influence & 0.38 & 1.12 & 0.34 \\
\hline Idealized behavioral influence & 1.00 & 2.58 & 0.06 \\
\hline Inspirational motivation & 0.33 & 1.11 & 0.35 \\
\hline Intellectual stimulation & 0.11 & 0.48 & 0.70 \\
\hline Individual consideration & 0.16 & 0.53 & 0.66 \\
\hline Contingent reward & 0.10 & 0.40 & 0.75 \\
\hline Management-by-exception active & 0.03 & 0.07 & 0.98 \\
\hline Management-by-exception passive & 0.30 & 0.61 & 0.61 \\
\hline Laissez-faire & 0.31 & 0.72 & 0.54 \\
\hline
\end{tabular}

Source: Own elaboration.

Additionally, to test if there is any difference between the type of media in each country, we run another ANOVA test. Results are shown in table 7.

Table 7. ANOVA test by country for every type of media

\begin{tabular}{|l|c|c|c|c|c|c|c|c|c|c|c|c|}
\hline & \multicolumn{3}{|c|}{ Press } & \multicolumn{3}{|c|}{ Radio } & \multicolumn{3}{c|}{ TV } & \multicolumn{3}{|c|}{ Web } \\
\hline Variable & MS & F & Prob & MS & F & Prob & MS & F & Prob & MS & F & Prob \\
\hline $\begin{array}{l}\text { Idealized attributed } \\
\text { influence }\end{array}$ & 0.02 & 0.05 & 0.82 & 0.02 & 0.12 & 0.73 & 0.26 & 1.14 & 0.30 & 0.01 & 0.09 & 0.78 \\
\hline $\begin{array}{l}\text { Idealized behavioral } \\
\text { influence }\end{array}$ & 0.00 & 0.00 & 1.00 & 1.13 & 6.31 & 0.03 & 0.86 & 2.05 & 0.17 & 0.01 & 0.07 & 0.8 \\
\hline $\begin{array}{l}\text { Inspirational } \\
\text { motivation }\end{array}$ & 0.43 & 1.52 & 0.22 & 0.01 & 0.13 & 0.72 & 2.00 & 5.67 & 0.03 & 0.09 & 0.27 & 0.62 \\
\hline $\begin{array}{l}\text { Intellectual } \\
\text { stimulation }\end{array}$ & 0.06 & 0.28 & 0.60 & 0.23 & 1.60 & 0.24 & 1.60 & 5.56 & 0.03 & 0.00 & 0.04 & 0.84 \\
\hline $\begin{array}{l}\text { Individual } \\
\text { consideration }\end{array}$ & 0.00 & 0.00 & 0.97 & 0.02 & 0.09 & 0.77 & 1.34 & 5.02 & 0.04 & 0.42 & 2.19 & 0.18 \\
\hline $\begin{array}{l}\text { Contingent reward } \\
\text { Management-by- }\end{array}$ & 0.02 & 0.07 & 0.79 & 0.55 & 1.95 & 0.20 & 1.65 & 7.59 & 0.01 & 0.22 & 2.33 & 0.17 \\
\hline $\begin{array}{l}\text { exception active } \\
\text { Management-by- }\end{array}$ & 2.43 & 4.11 & 0.05 & 0.00 & 0.00 & 1.00 & 1.03 & 3.93 & 0.06 & 0.00 & 0.01 & 0.94 \\
\hline $\begin{array}{l}\text { exception passive } \\
\text { Laissez-faire }\end{array}$ & 0.32 & 0.57 & 0.45 & 0.01 & 0.04 & 0.84 & 0.12 & 0.44 & 0.52 & 0.00 & 5.15 & 0.06 \\
\hline
\end{tabular}

Source: Own elaboration.

We see that for television there is differences between Spain and Chile in the way in which the participants see their leadership. In print media (daily newspapers and magazines) and radio, the leadership style is considered as based on inspiration: the communication of an ideal future company that has the potential to be shared (Yaslioglu $\&$ Erden, 2018). However, in television and Internet managers there is a wider recognition of idealized behavioral influence, the more charismatic aspect of transformational leaders, where they become role models that can be admired by their employees (Sy, 
Horton, \& Riggio, 2018). Idealized influence has also been related to the leaders' ethical integrity (Leroy, Palanski, \& Simons, 2012).

We also checked if there is any difference between the type of leadership and the tenure of the manager as a director. As table 8 and 9 shows, we did not find any difference between the evaluation of leadership styles and the tenure of the manager as a director.

Table 8. Comparison of variables by tenure in a directive position

\begin{tabular}{|c|c|c|c|c|c|c|}
\hline & \multicolumn{2}{|c|}{ Total } & \multicolumn{2}{|c|}{ 1-10 years } & \multicolumn{2}{|c|}{ More than 11 years } \\
\hline Variable & Mean & SD & Mean & SD & Mean & SD \\
\hline $\begin{array}{l}\text { Idealized attributed } \\
\text { influence }\end{array}$ & 2.98 & 0.59 & 2.94 & 0.59 & 3.09 & 0.59 \\
\hline $\begin{array}{l}\text { Idealized behavioral } \\
\text { influence }\end{array}$ & 3.11 & 0.67 & 3.06 & 0.63 & 3.24 & 0.76 \\
\hline Inspirational motivation & 3.09 & 0.56 & 3.08 & 0.54 & 3.12 & 0.63 \\
\hline Intellectual stimulation & 3.09 & 0.49 & 3.10 & 0.45 & 3.08 & 0.59 \\
\hline Individual consideration & 3.08 & 0.59 & 3.05 & 0.59 & 3.17 & 0.58 \\
\hline Contingent reward & 3.12 & 0.48 & 3.15 & 0.48 & 3.05 & 0.48 \\
\hline $\begin{array}{l}\text { Management-by-exception } \\
\text { active }\end{array}$ & 2.33 & 0.72 & 2.36 & 0.69 & 2.26 & 0.81 \\
\hline $\begin{array}{l}\text { Management-by-exception } \\
\text { passive }\end{array}$ & 0.86 & 0.74 & 0.87 & 0.72 & 0.85 & 0.80 \\
\hline Laissez-faire & 0.53 & 0.70 & 0.50 & 0.60 & 0.63 & 0.94 \\
\hline
\end{tabular}

Source: Own elaboration.

Table 9. ANOVA test by tenure in a directive position

\begin{tabular}{|l|c|c|c|}
\hline Variable & MS & F & Prob \\
\hline Idealized attributed influence & 0.32 & 0.92 & 0.34 \\
\hline Idealized behavioral influence & 0.48 & 1.08 & 0.30 \\
\hline Inspirational motivation & 0.03 & 0.08 & 0.77 \\
\hline Intellectual stimulation & 0.00 & 0.02 & 0.90 \\
\hline Individual consideration & 0.21 & 0.60 & 0.44 \\
\hline Contingent reward & 0.16 & 0.69 & 0.41 \\
\hline Management-by-exception active & 0.15 & 0.28 & 0.60 \\
\hline Management-by-exception passive & 0.00 & 0.01 & 0.94 \\
\hline Laissez-faire & 0.23 & 0.46 & 0.50 \\
\hline
\end{tabular}

Source: Own elaboration. 
Table 10. Exploratory factor analysis (Chile and Spain)

\begin{tabular}{|l|l|l|l|}
\hline Indicators & Factor1 & Factor2 & Factor3 \\
\hline Strategic Decisions & 0,714 & & \\
& 0,765 & & \\
& 0,885 & & \\
& 0,906 & & \\
& 0,880 & & \\
& 0,873 & & \\
\hline Employee & & 0,791 & \\
participation & & 0,699 & \\
& & 0,678 & \\
& & 0,739 & \\
\hline Motivation & & & 0,787 \\
& & & 0,773 \\
\hline & & & 0,778 \\
\hline
\end{tabular}

Note: Cronbach alphas were calculated for each of the factors presented in Table 4, $\mathrm{p}<0.05$.

Source: Own elaboration.

In order to measure the indicators' consistency in the second part of our questionnaire, an exploratory factor analysis was conducted. We complemented it calculating the Cronbach alphas of each of the indicators. Our 14 indicators could be grouped in three main factors (see table 10): the first refers to strategic decisions. It tries to measure whether best practices from innovative industry companies are adopted; to what extent company people are promoted and retained, and how new technologies are adopted. The second is related to participation: it groups variables such as the leaders' initiatives to make employees part of the decision making, take risk or propose new ways to solve problems. The third is associated to motivation and the active promotion of creativity and other intangibles of organizations.

We calculate linear regression of each variable, we propose two models. The first one considering the three types of leadership measured in our study: transformational leadership, transactional leadership and Laissez-faire leadership. In the second model we include two control variables: tenure of the manager in a directive position, and type of media. Results are shown in table 11.

Table 11. Regression

\begin{tabular}{|l|c|c|c|c|c|c|}
\hline & \multicolumn{3}{|c|}{ Model 1 } & \multicolumn{3}{c|}{ Model 2 } \\
\hline Strategic Decisions & Coef. & SE & t & Coef. & SE & t \\
\hline Transformational Leadership & $-19.16^{* *}$ & 8.22 & -2.33 & $-23.53 * *$ & 11.44 & -2.06 \\
\hline Transactional Leadership & -0.35 & 5.96 & -0.06 & -0.96 & 8.48 & -0.11 \\
\hline Laissez-faire leadership & -1.91 & 5.03 & -0.38 & -5.01 & 7.19 & -0.70 \\
\hline Tenure in directive position & & & & 0.04 & 0.04 & 1.03 \\
\hline Type of media & & & & -1.62 & 3.27 & -0.49 \\
\hline
\end{tabular}




\begin{tabular}{|c|c|c|c|c|c|c|}
\hline Gender & & & & 6.53 & 9.54 & 0.68 \\
\hline Constant & $72.11 * * *$ & 24.55 & 2.94 & $78.51 * *$ & 38.28 & 2.05 \\
\hline $\mathrm{F}$ & $2.67 * *$ & & & 1.73 & & \\
\hline df & 3 & & & 6 & & \\
\hline Employee participation & Coef. & SE & $\mathbf{t}$ & Coef. & SE & $\mathbf{t}$ \\
\hline Transformational Leadership & $-17.78 * *$ & 8.08 & -2.20 & $-22.26 * *$ & 11.19 & -1.99 \\
\hline Transactional Leadership & -1.15 & 5.90 & -0.20 & -1.50 & 8.39 & -0.18 \\
\hline Laissez-faire leadership & -2.16 & 5.00 & -0.43 & -5.60 & 7.02 & -0.80 \\
\hline Tenure in directive position & & & & 0.04 & 0.04 & 1.12 \\
\hline Type of media & & & & -1.50 & 3.25 & -0.46 \\
\hline Gender & & & & 7.97 & 9.10 & 0.88 \\
\hline Constant & $69.95 * * *$ & 24.37 & 2.87 & $72.99 * *$ & 36.82 & 1.98 \\
\hline $\mathrm{F}$ & $2.49 *$ & & & 1.72 & & \\
\hline df & 3 & & & 6 & & \\
\hline Motivation & Coef. & SE & $\mathbf{t}$ & Coef. & SE & $\mathbf{t}$ \\
\hline Transformational Leadership & $-17.95 * *$ & 8.06 & -2.23 & $-22.43 * *$ & 11.15 & -2.01 \\
\hline Transactional Leadership & -0.97 & 5.89 & -0.17 & -1.36 & 8.37 & -0.16 \\
\hline Laissez-faire leadership & -2.13 & 4.99 & -0.43 & -5.53 & 7.00 & -0.79 \\
\hline Tenure in directive position & & & & 0.04 & 0.04 & 1.14 \\
\hline Type of media & & & & -1.51 & 3.24 & -0.47 \\
\hline Gender & & & & 7.86 & 9.07 & 0.87 \\
\hline Constant & $70.10 * * *$ & 24.32904 & 2.88 & $73.44 * *$ & 36.70 & 2.00 \\
\hline $\mathrm{F}$ & $2.52 *$ & & & 1.74 & & \\
\hline df & 3 & & & 6 & & \\
\hline
\end{tabular}

Source: Own elaboration.

The third question our research tried to investigate was whether size, media, ownership or years of existence were relevant factors for innovation and creativity in media organizations. Results are shown in Table 12.

We did not find any evidence that the firm size, the type of ownership, the distribution system or the year of existence is correlated with the leadership practices.

According to the perceptions of the managers and editors who answered our questionnaire, we did not find evidence that supports that case. A $71 \%$ of our respondents in Chile and a 66\% in Spain considered that both small and large companies can foster innovative and creative cultures. The situation is similar in terms of ownership, where a $72 \%$ in Chile and $66 \%$ in Spain said that diversification or familiar ownership are not relevant factors. The medium was only a factor in the case of online platforms, that were considered to create better conditions for innovation and creativity by a $68 \%$ of our Chilean respondents and a $57 \%$ of our Spanish ones (the difference between both countries was here more significant). Finally, when we looked into the organizations' 
years of existence, a $68 \%$ in Chile and a $57 \%$ in Spain said that when it comes to innovation and creativity it did not matter how old a company is.

Table 12. Correlation between leadership practice and firm's size, type of ownership, distribution system, and years of existence.

\begin{tabular}{|c|c|c|c|c|c|c|c|c|}
\hline & & 1 & 2 & 3 & 4 & 5 & 6 & 7 \\
\hline 1 & Transformational Leadership & 1.00 & & & & & & \\
\hline 2 & Transactional Leadership & $0.50 * * *$ & 1.00 & & & & & \\
\hline 3 & Laissez-faire leadership & $-0.38 * * *$ & -0.09 & 1.00 & & & & \\
\hline 4 & Firm's Size & 0.21 & 0.17 & 0.14 & 1.00 & & & \\
\hline 5 & Type of ownership & 0.12 & -0.10 & 0.11 & 0.08 & 1.00 & & \\
\hline 6 & Distribution system & -0.11 & 0.11 & -0.02 & 0.09 & -0.12 & 1.00 & \\
\hline 7 & Years of existence & -0.18 & -0.08 & 0.10 & 0.06 & 0.14 & -0.07 & $\begin{array}{c}1.0 \\
0\end{array}$ \\
\hline
\end{tabular}

Source: Own elaboration.

\section{Discussion, future research and limitations}

Our results find a group of managers that have good opinions of their transformative qualities: they believe they have the ability to inspire, share goals and understand what is important, perhaps somewhat in contrast with the working experiences of their employees that often have a low opinion of media companies as places to work. In the second phase of this work we will study the perception of journalist to improve our understanding of the causes of this disconnect.

In the media industry leadership is considered crucial. But the sector has been underperforming and yet leaders are not very critical about their work. Our hypothesis could be summarized by saying that that is precisely the problem. Further research could ask the same time of questions to employees in order to find out their opinions and confirm this hypothesis.

The findings underline the value of idealized behavioral influence, which appears as an element that sheds light on a crucial value for journalists: integrity. The industry needs leaders that understand media's mission and societal role, and high scores for idealized behavioral influence point in that direction. Innovative thinking was also stressed by our intellectual stimulation indicator, showing the need to support employees' ideas and values and behaviors that could be considered disruptive. This element could be considered crucial in the media industry, where there is a widespread recognition of the need for change. The consequences of these findings seem valuable as innovative thinking tends to support creativity, which at the same time might enhance effectiveness in the industry.

Not all the media are the same. Our research finds some differences in the way participants see leadership in different media. Leadership styles tend to be perceived as more inspirational in print media and radio. In television and the Internet, however, the more charismatic aspects of transformational leaders are considered more often. Our 
sample was too small to measure deeply each different medium but we think these findings deserve further research focusing in each medium's specific characteristics.

Evidence supporting the idea that size, media, ownership or years of existence are perceived by leaders as relevant factors for innovation and creativity in media organizations was not found. The medium appeared to be a factor only in the case of online platforms that were considered to create better environments for innovation and creativity. This seem to point to the idea that leadership is more important for innovation and creativity that any of those factors, which might underline the purpose of our research.

The main limitations of our study are due to the fact that we cover just two countries. Our sample is not large enough to understand the situation in each medium: in the survey there are managers from every medium but for some media the number of respondents is limited. Also, it is well known that a survey methodology gives impressions from leaders that talk about their views and tend to say what it is expected about leadership and working environments. Some ethnographic research could be added not just to talk about behaviors but actually observe them.

Research of leadership in the media industry appears to be an increasingly necessary research venue. The ever changing nature of the industry is leading to the perception that people are key "assets" for company success. And people need to be led by outstanding managers that inspire, sustain their efforts and foster innovative environments.

In our complex landscape, to do the same or something quite similar to what was done yesterday is not likely to be a recipe for success. Leadership demands for success evolve more towards softer skills combined with abilities to motivate teams and agility and flexibility to embrace change. Therefore, fast innovations and more competition in the media industry require a high degree of leadership: without an increased capacity to change, companies are left behind. When transformations are not quiet and linear, they demand new strategies, business models and processes to create value. Our work opens new venues for further research adding to the scholarly work that reminds us that leadership is one of the main sources of competitive advantages in turbulent times.

\section{References}

Achap (2018). Inversión en Comunicaciones Publicitarias. Retrived from http://www.achap.cl/wp-content/uploads/2018/06/Inversion-Publicitaria-2017-ok.pdf

Afuah, A. (2014). Business Model Innovation: : concepts, analysis, and cases. Routledge: New York.

Aga, D. A., Noorderhaven, N., \& Vallejo, B. (2016). Transformational leadership and project success: The mediating role of team-building. International Journal of Project Management, 34(5), 806-818.

Álvarez Hormazábal, M. I. (2016). Los determinantes de la audiencia televisiva de mega-eventos deportivos en Chile: el caso de las Copas del Mundo FIFA. Tesis para optar al grado de Magister en Marketing. Retrieved from: http://repositorio.uchile.cl/handle/2250/138718.

Amabile, T. M. (1998). How to kill creativity (Vol. 87). Boston, MA: Harvard Business School Publishing. 
Antonakis, J., \& Day, D. V. (Eds.). (2017). The nature of leadership. Sage publications.

Atmojo, M. (2015). The influence of transformational leadership on job satisfaction, organizational commitment, and employee performance. International research journal of business studies, 5(2).

Avolio, B. J. \& Bass, B. M. (2004). MLQ: Multifactor leadership questionnaire. Mind Garden.

Bass, B. M. (1999). Two decades of research and development in transformational leadership. European journal of work and organizational psychology, 8(1), 9-32.

Bass, B. M. \& Avolio, B. J. (1994). Transformational leadership and organizational culture. The International Journal of Public Administration, 17(3-4), 541-554.

Bass, B. M. \& Avolio, B. J. (2000). Multifactor leadership questionnaire: MLQ; sampler set; technical report, leader form, rater form, and scoring key for MLQ form 5x-short. Mind Garden.

Bass, B. M. \& Riggio, R. E. (2006). Transformational leadership. Psychology Press.

Benavides, C. (2012). Innovation and Leadership in the Media Industry. Media Markets Monographs, 13. Pamplona.

Benavides, C. (2017). Estilos de liderazgo en las redacciones chilenas: estudio de la autopercepción de los directivos. Cuadernos info, (41), 123-140.

Bennis, W. (1989). On Becoming a Leader. Addison-Wesley: Reading, Mass.

Breevaart, K., \& Bakker, A. B. (2018). Daily job demands and employee work engagement: The role of daily transformational leadership behavior. Journal of occupational health psychology, 23(3), 338.

Burns, J. M. (2003). Transforming leadership: A new pursuit of happiness (Vol. 213). Grove Press.

Cardona, P. (2000). Transcendental leadership. Leadership \& Organization Development Journal, 21(4), 201-207.

Černe, M., Jaklič, M., \& Škerlavaj, M. (2013). Authentic leadership, creativity, and innovation: A multilevel perspective. Leadership, 9(1), 63-85.

Chalofsky, N. \& Krishna, V. (2009). Meaningfulness, commitment, and engagement: The intersection of a deeper level of intrinsic motivation. Advances in Developing Human Resources, 11(2), 189-203.

Colbert, A. E., Barrick, M. R. \& Bradley, B. H. (2014). Personality and leadership composition in top management teams: Implications for organizational effectiveness. Personnel Psychology, 67(2), 351-387.

Czech, K. \& Forward, G. L. (2013). Communication, leadership, and job satisfaction: Perspectives on supervisor-subordinate relationships. Studies in media and Communication, 1(2), 11-24.

Dal Zotto, C. \& Van Kranenburg, H. (eds.). (2008). Management and innovation in the media industry. Edward Elgar Publishing.

Deslandes G. (2016). Leadership in Media Organisations: Past Trends and Challenges Ahead. In: Lowe G., Brown C. (eds) Managing Media Firms and Industries. Media Business and Innovation. Springer, Cham. 
Djibo, I. J., Desiderio, K. P. \& Price, N. M. (2010). Examining the role of perceived leader behavior on temporary employees' organizational commitment and citizenship behavior. Human Resource Development Quarterly, 21(4), 321-342.

Dogruel, L. (2014). What is so special about media innovations? A characterization of the field. The Journal of Media Innovations, 1(1), 52-69.

Doyle, G. (2016). Digitization and changing windowing strategies in the television industry: negotiating new windows on the world. Television \& New Media, 17(7), 629645.

Eberly, M. B., Bluhm, D. J., Guarana, C., Avolio, B. J., \& Hannah, S. T. (2017). Staying after the storm: How transformational leadership relates to follower turnover intentions in extreme contexts. Journal of Vocational Behavior, 102, 72-85.

Fairhurst, G. T. \& Connaughton, S. L. (2014). Leadership: A communicative perspective. Leadership, 10(1), 7-35.

Gal-Or, E. \& Dukes, A. (2003). Minimum differentiation in commercial media markets. Journal of Economics \& Management Strategy, 12(3), 291-325.

Gillet, N. \& Vandenberghe, C. (2014). Transformational leadership and organizational commitment: The mediating role of job characteristics. Human Resource Development Quarterly, 25(3), 321-347.

Gomery, D. (1993). The centrality of media economics. Journal of Communication, 43(3), 190-198.

Kiarie, M. A. W., Maru, L. C., \& Cheruiyot, T. K. (2017). Leader personality traits and employee job satisfaction in the media sector, Kenya. The TQM Journal, 29(1), 133-146.

Küng, L. (ed.) (2006). Leadership in the Media Industry: Changing Contexts, Emerging Challenges. JIBS Research Reports No. 2006-1. Jonköping: Media Management and Transformation Centre

Hon, A. H. (2012). Shaping environments conductive to creativity: The role of intrinsic motivation. Cornell Hospitality Quarterly, 53(1), 53-64.

Imran, M. K., Ilyas, M., Aslam, U., \& Fatima, T. (2018). Knowledge processes and firm performance: the mediating effect of employee creativity. Journal of Organizational Change Management, 31(3), 512-531.

InfoAdex (2018). Estudio Infoadex de la inversión publicitaria en españa 2018. Retrieved from http://www.infoadex.es/home/wp-content/uploads/2018/02/Estudio-InfoAdex2018.pdf

Jackson, T. A., Meyer, J. P. \& Wang, X. H. F. (2013). Leadership, Commitment, and Culture A Meta-Analysis. Journal of Leadership \& Organizational Studies, 20(1), 84106.

Jaiswal, N. K. \& Dhar, R. L. (2015). Transformational leadership, innovation climate, creative self-efficacy and employee creativity: A multilevel study. International Journal of Hospitality Management, 51, 30-41.

Jenkins, H., Ford, S. \& Green, J. (2013). Spreadable media: Creating value and meaning in a networked culture. NYU Press

Jensen, U. T., Andersen, L. B., Bro, L. L., Bøllingtoft, A., Eriksen, T. L. M., Holten, A. L., ... \& Westergård-Nielsen, N. (2019). Conceptualizing and measuring transformational 
and transactional leadership. Administration \& Society, 51(1), 3-33.

Judge, T. A. \& Piccolo, R. F. (2004). Transformational and transactional leadership: a meta-analytic test of their relative validity. Journal of applied psychology, 89(5), 755.

Kirkbride, P. (2006). Developing transformational leaders: the full range leadership model in action. Industrial and commercial training, 38(1), 23-32.

Koccedil, H. (2011). The impact of managers leadership behaviors on job satisfaction and performance of employees. African Journal of Business Management, 5(30), 1183611843.

Koryak, O., Mole, K. F., Lockett, A., Hayton, J. C., Ucbasaran, D. \& Hodgkinson, G. P. (2015). Entrepreneurial leadership, capabilities and firm growth. International Small Business Journal, 33(1), 89-105.

Kotter, J. P. (1982). The General Managers. Free Press: Nueva York.

Leroy, H., Palanski, M. E., \& Simons, T. (2012). Authentic leadership and behavioral integrity as drivers of follower commitment and performance. Journal of Business Ethics, 107(3), 255-264.

Mellado, C., Salinas, P., Del Valle, C. \& González, G. (2010). Estudio comparativo de cuatro regiones: mercado laboral y perfil del periodista/A comparative study in four regions: Labor market and profile of the Chilean journalist. Cuadernos info, (26), 45-64.

Men, L. R. (2014). Strategic Internal Communication: Transformational Leadership, Communication Channels, and Employee Satisfaction. Management Communication Quarterly, 28(2), 264-284. https://doi.org/10.1177/0893318914524536

Mitchell, A. \& Holcomb, J. (2016). State of the news media 2016. Pew Research Center.

Mittal, S. \& Dhar, R. L. (2015). Transformational leadership and employee creativity: mediating role of creative self-efficacy and moderating role of knowledge sharing. Management Decision, 53(5), 894-910. doi.org/10.1108/MD-07-2014-0464

Nieves, J., Quintana, A. \& Osorio, J. (2014). Knowledge-based resources and innovation in the hotel industry. International Journal of Hospitality Management, 38, 65-73.

Northouse, P. (2004). Leadership Theory and Practice. Thousand Oaks, California: SAGE Publications.

Palacio Llanos, L. (2015). Informe Anual de la Profesión Periodística. Asociación de la Prensa de Madrid.

Pérez-Latre, F. (2014). Legacy media: a case for creative destruction? Palabra Clave, 17(4), 1097-1113.

Pérez-Latre, F. J. \& Sánchez-Tabernero, A. (2003). Leadership, an essential requirement for effecting change in media companies: An analysis of the Spanish market. International Journal on Media Management, 5(3), 199-208.

Peters, T. (1987). Thriving on chaos: Handbook for a managerial revolution. New York: Alfred A. Knopf.

Picard, R. G. \& Chon, B. S. (2004). Managing competition through barriers to entry and channel availability in the changing regulatory environment. International Journal on Media Management, 6(3-4), 168-175.

Pilbeam, C., Doherty, N., Davidson, R. \& Denyer, D. (2016). Safety leadership practices 
for organizational safety compliance: Developing a research agenda from a review of the literature. Safety science, 86, 110-121. doi: 10.1016/j.ssci.2016.02.015

Podsakoff, P. M., MacKenzie, S. B., Moorman, R. H. \& Fetter, R. (1990). Transformational leader behaviors and their effects on followers' trust in leader, satisfaction, and organizational citizenship behaviors. The Leadership Quarterly, 1(2), 107-142.

Qu, R., Janssen, O. \& Shi, K. (2015). Transformational leadership and follower creativity: The mediating role of follower relational identification and the moderating role of leader creativity expectations. The Leadership Quarterly,26(2), 286-299. doi: 10.1016/j.leaqua.2014.12.004

Reuters Institute for the Study of Journalism (2016). Digital News Report. Oxford.

Rubin, R. S., Munz, D. C. \& Bommer, W. H. (2005). Leading from within: The effects of emotion recognition and personality on transformational leadership behavior. Academy of Management Journal, 48(5), 845-858.

Sánchez, Á. J. \& de la Cavada, J. M. L. (2018). Industrias culturales y composición de los personajes en las series de animación infantil emitidas en España. Revista Latina de Comunicación Social, (73), 74-85.

Sánchez-Tabernero, A. (2008). Los contenidos de los medios de comunicación: calidad, rentabilidad y competencia. Ediciones Deusto.

Shanker, R., Bhanugopan, R., Van der Heijden, B. I., \& Farrell, M. (2017). Organizational climate for innovation and organizational performance: The mediating effect of innovative work behavior. Journal of vocational behavior, 100, 67-77.

Skogstad, A., Einarsen, S., Torsheim, T., Aasland, M. S. \& Hetland, H. (2007). The destructiveness of laissez-faire leadership behavior. Journal of occupational health psychology, 12(1), 80.

Sy, T., Horton, C., \& Riggio, R. (2018). Charismatic leadership: Eliciting and channeling follower emotions. The Leadership Quarterly, 29(1), 58-69.

Tansky, J. W. \& Cohen, D. J. (2001). The relationship between organizational support, employee development, and organizational commitment: An empirical study. Human Resource Development Quarterly, 12(3), 285-300.

Uusi-Kakkuri, P. (2017). Transformational leadership and leading creativity. Acta Wasaensia, 376.

Vroom, V. H. \& Jago, A. G. (2007). The role of the situation in leadership. American psychologist, 62(1), 17.

Wang, M. S. (2010). Influence of knowledge sharing and project complexity on group creativity: taking the development of information system for example. Journal of $e$ Business, 12(1), 73-102.

Xiaoming, H., George, C. \& Cong, S. (2013). Job satisfaction of journalists: Professional aspirations, newsroom culture and social context. Media Asia, 40(1), 73-84.

Yaslioglu, M. M., \& Erden, N. S. (2018). Transformational Leaders in Action: Theory Has Been There, But What About Practice? IUP Journal of Business Strategy, 15(1), 4253.

Yukl, G. (2002). Leadership in organizations (5th ed.). NJ: Prentice Hall. 
Zhang, X. \& Bartol, K. M. (2010). Linking empowering leadership and employee creativity: The influence of psychological empowerment, intrinsic motivation, and creative process engagement. Academy of management journal, 53(1), 107-128.

Zhou, J. \& George, J. M. (2001). When job dissatisfaction leads to creativity: Encouraging the expression of voice. Academy of management journal, 44(4), 682-696.

Zwingmann, I., Wegge, J., Wolf, S., Rudolf, M., Schmidt, M. \& Richter, P. (2014). Is transformational leadership healthy for employees? A multilevel analysis in 16 nations. German Journal of Human Resource Management, 28(1-2), 24-51. doi: $10.1177 / 23970022$ 